\title{
The International Criminal Court's Impact on Peacebuilding in Africa
}

\author{
Phil Clark
}

\section{INTRODUCTION}

The International Criminal Court (ICC), the first permanent, global institution mandated to investigate and prosecute cases of genocide, war crimes, and crimes against humanity, has transformed the African peacebuilding terrain since it came into force in 2002. Over the last 17 years, the ICC has generated considerable controversy, including criticism of its impact on peace processes in Africa, the continent that-except for the 2016 opening of ICC investigations into the Russia/Georgia conflicthas provided all of the Court's situations to date. Concerns over the effect of international criminal justice on African peace and reconciliation initiatives are not new, having arisen with two previous institutions, the UN International Criminal Tribunal for Rwanda (ICTR) and the Special Court for Sierra Leone (SCSL). ${ }^{1}$ This issue is more acute with the ICC, however, because its temporal mandate, which limits the Court to investigating and prosecuting cases after July 1, 2002, increases the likelihood

P. Clark $(\bowtie)$

SOAS University of London, London, UK

e-mail: pc44@soas.ac.uk

(C) The Author(s) 2021

T. McNamee and M. Muyangwa (eds.),

The State of Peacebuilding in Africa, https://doi.org/10.1007/978-3-030-46636-7_14 
of the Court intervening in situations of ongoing conflict and intersecting with a wide range of conflict mitigation processes.

This chapter examines the ICC's intersections with two widespread domestic conflict resolution processes in Africa, national amnesties and peace negotiations. In doing so, it connects to two overarching scholarly and policy debates, namely the appropriateness and legality of amnesties as opposed to prosecutions for suspected perpetrators of international crimes ${ }^{2}$ and the "peace versus justice" debate over whether the threat of prosecution imperils peace negotiations that involve high-level atrocity suspects. ${ }^{3}$ These issues coincided during the Juba peace talks between the Ugandan government and the Lord's Resistance Army (LRA) rebels, starting in 2006, one year after the ICC issued arrest warrants for the top five LRA commanders while a national amnesty for all rebel combatants was still in place. The tensions around Juba ignited the entire fields of transitional justice and peacebuilding, as witnessed in the landmark "Building a Future on Peace and Justice" conference in Nuremberg in June 2007. ${ }^{4}$ The event was held at the height of the Juba talks amid calls for the deferral or withdrawal of the ICC charges against the LRA leadership for the sake of peace. The conference was attended by the ICC Prosecutor, Registrar, and other senior Court officials, who used it as a platform to pronounce on developments in Juba. ${ }^{5}$ This included the lament by the ICC's inaugural chief prosecutor Luis Moreno-Ocampo that "we...hear officials of States Parties calling for amnesties, the granting of immunities and other ways to avoid prosecutions, supposedly in the name of peace." 6

This chapter argues that the ICC has generally ridden roughshod over national choices to employ amnesties to facilitate peace negotiations and other responses to violence across Africa, including security sector reform (SSR), disarmament, demobilization, and reintegration (DDR) and truth commissions. The ICC's and its supporters' vehement insistence on a narrow brand of international criminal justice has undermined these important attempts to resolve conflict and often made peace less, rather than more, likely. This chapter focuses on the ICC's first twoand therefore most developed-situations in northern Uganda and the Democratic Republic of the Congo (DRC), with secondary reference to Rwanda, South Sudan, and other conflict-affected states in Africa. The Uganda and DRC situations, analyzed sequentially below in sections dedicated to domestic amnesties and peace negotiations, highlight a range of ICC-induced problems for peacebuilding in African states. The chapter concludes with some lessons from the ICC's interventions for recrafting international criminal justice in support of the wider pursuit of peace. 


\section{Domestic Amnesties}

International criminal law is now a central feature of most peace negotiations around the world, especially those involving United Nations (UN) mediation. The UN increasingly holds that international law prohibits the use of amnesties for suspects of genocide, war crimes, and crimes against humanity and therefore insists on prosecutions within the framework of peace negotiations. ${ }^{7}$ Meanwhile, the ICC has regularly briefed international mediators about the illegality of using amnesties for this category of suspects during peace talks. ${ }^{8}$ This signifies a substantial shift since the 1998 conference in Rome that led to the signing of the ICC Statute, where many delegates expressed sympathy for the model of amnesty central to the South African Truth and Reconciliation Commission (TRC), which was underway at the time. ${ }^{9}$ Philippe Kirsch, the chair of the Preparatory Commission in Rome and later the first President of the ICC, stated that the Rome Statute purposely contains a "creative ambiguity"10 that gives substantial discretion when considering amnesties. ${ }^{11}$

As various commentators have pointed out, international criminal law does not clearly prohibit the use of amnesties for serious crimes. ${ }^{12}$ The Rome Statute does not mention amnesties, although the ICC's definition of the "genuine proceedings" by domestic institutions that would prevent ICC intervention encompasses only national prosecutions. Other international criminal law statutes and conventions meanwhile are less prescriptive or say very little about this issue. This suggests that the international legal basis for the trend against amnesties is significantly weaker than many advocates have proposed, necessitating a different set of justifications by the UN and other international practitioners for their anti-amnesty stance. Various scholars also challenge the widespread assumption that international trials inherently deter crimes and produce long-term stability and that amnesties foster impunity and ultimately undermine peace and social order. ${ }^{13}$

\section{Domestic Amnesties in Uganda}

The Uganda and DRC situations highlight various ways in which the ICC has undermined national amnesties and, by extension, a range of DDR and SSR programs that depend on incentivizing combatants' cooperation through the offer of amnesties. From the beginning of its operations 
in Uganda, the ICC opposed the use of the country's Amnesty Act for high-level suspects of international crimes on the grounds that it violated the Rome Statute and entrenched impunity. This opposition reached a crescendo during the 2006-2008 Juba peace talks, where the ICC Office of the Prosecutor (OTP) issued regular dismissals of the LRA's attempts to secure an amnesty for its leaders, amplified by a constant stream of press releases and communiqués by international human rights organizations. ${ }^{14}$ This section argues that the pronouncements by the ICC and its supporters belied the long-term use of amnesties in Uganda even before the emergence of the LRA; the widespread support for the Amnesty Act among everyday Ugandans, including its use for senior LRA commanders; and the tangible, positive effects of the amnesty policy.

The Amnesty Act stemmed from lobbying by the Acholi Religious Leaders Peace Initiative (ARLPI) during the 1999 peace talks between the Ugandan government, the LRA and the LRA's principal backer, the Sudanese government. The ARLPI conducted widespread consultations with northern victims' groups and concluded there was a strong desire among the population for personal and collective healing and reconciliation with the rebels. ${ }^{15}$

The impact of the Ugandan amnesty process has been substantial. To date, approximately 30,000 rebels have come in from the bush under the DDR process facilitated by the amnesty, including senior LRA commanders such as Brigadier Kenneth Banya and Brigadier Sam Kolo. ${ }^{16}$ Because of the quantifiable impact of the amnesty process, various empirical studies highlight widespread popular support for the policy. ${ }^{17}$ In 2012, the Ugandan government let the Amnesty Act lapse for the first time since its promulgation but sustained pressure from northern Ugandan civil society forced the government to reinstate the Act in $2013 .{ }^{18}$

The ICC's and its supporters' opposition to the Amnesty Act is highly problematic for two main reasons. First, these actors ignore the substantial support for the Act among everyday Ugandans. In the late 1980s and 1990s, there was considerable support for amnesty processes because of their success in disarming and reintegrating the Uganda People's Democratic Army (UPDA) and the Uganda People's Army (UPA) in 1987, ${ }^{19}$ and the West Nile Bank Front (WNBF) in $1998 .{ }^{20}$ Furthermore, as highlighted in a 2007 study by the UN Office of the High Commissioner for Human Rights (OHCHR), widespread approval for processes of amnesty, forgiveness, and reconciliation (which most respondents define 
discretely) emerges because many northern Ugandans view the perpetrators of violence as their own children who must be treated leniently and eventually reintegrated into the community. ${ }^{21}$ This often extends to LRA leaders such as Kony, whom many northern Ugandans consider a "child of the community" who should be encouraged through the amnesty process to halt the rebellion and return "home." 22 The Uganda case thus directly challenges the oft-stated view that the use of amnesty hampers a long-term transition toward democracy. Uganda represents an example of a democratic amnesty, which resulted from civil society lobbying and widespread popular consultations, rather than government diktat. International opposition to such a democratic amnesty may therefore undermine democracy in the long run.

Second, the confusion over the applicability of the Amnesty Actwhether the amnesty is still in place and to whom it applies-generated both by the ICC and the Ugandan government (which has responded to donor pressure to shift toward a more legalistic, punitive framework for transitional justice $)^{23}$ has greatly undermined the Act's effectiveness in catalyzing the DDR of LRA and other rebel combatants. The Ugandan Amnesty Commission and various civil society groups have reported over the last decade the substantial reduction in combatants returning from the bush under the Amnesty Act, which they attribute directly to the perceived threat of prosecution. ${ }^{24}$ This highlights the ICC's and Ugandan government's tangible undermining of DDR as a peacebuilding process, through their continued opposition to the use of amnesties for rebel combatants.

\section{Domestic Amnesties in the Democratic Republic of the Congo}

The DRC has instituted a much wider range of amnesty processes than Uganda for a broader set of purposes. Whereas Uganda has used a single Amnesty Act, connected to an overarching DDR process for returning rebels, the DRC has passed four amnesty laws since 2002, linked explicitly to a truth and reconciliation commission (TRC) and an SSR program involving the brassage or "mixing" of former rebels into the national Congolese army. Concurrent to these DRC amnesty laws, an implicit amnesty policy has supported an extensive DDR program for Congo-based Rwandan rebels. Three phases of DDR since 1998 have demobilized around 35,000 mainly Hutu former combatants from 
eastern DRC. The majority of these fighters are members of the Democratic Forces for the Liberation of Rwanda (FDLR) and the former Rwandan army which fled across the border after the 1994 genocide against the Tutsi. ${ }^{25}$

Two important problems regarding the ICC and amnesties have emerged in the DRC. First, echoing the Ugandan situation, the Congolese government's variability on the use of amnesties-under pressure from the ICC and international human rights organizations-has weakened their effectiveness as a peacebuilding tool. Generally, the Congolese government has displayed a much greater readiness to give amnesties to senior military and rebel leaders as part of the country's SSR program than implied by its self-portrayal as an unyielding friend of international justice. ${ }^{26}$ Acting outside of the 2005 amnesty law, in 2006 the then-President Joseph Kabila pardoned Mathieu Ngudjolo and all 10,000 members of his Ituri rebel coalition, the Mouvement Révolutionnaire Congolais (MRC), as well as the rebel groups led by Peter Karim and Cobra Matata, in exchange for their surrender, the decommissioning of their weapons, and their integration into the Congolese army. ${ }^{27}$ As a result, all three leaders were promoted to the rank of colonel.

Such a practice was common in the lead-up to the 2006 national elections, as the government sought to minimize the impact of militia groups capable of intimidating voters and disrupting preparations for the poll. The UN Organization Mission in the Democratic Republic of the Congo (MONUC) ${ }^{28}$ supported the scheme as part of the UN's broader disarmament program in eastern DRC. Kemal Saiki, a MONUC spokesperson, defended the amnesty-for-peace deals with Ngudjolo, Karim, and Matata: "The most important thing is to bring an end to the bloodshed. Since these deals have been signed, there has not been any large-scale fighting in Ituri." 29

The Congolese government's ambiguity on questions of amnesty continued when in February 2008 it arrested Ngudjolo at a military training camp in Kinshasa following an ICC warrant issued in July 2007. This amounted to a "bait and switch," with Ngudjolo lured into surrender from his rebel ranks and integrated into the Congolese army, only to be arrested and transferred to The Hague for prosecution 18 months later. While the Congolese government was widely hailed for its cooperation in arresting and transferring Ngudjolo to the ICC, its duplicity toward an amnesty recipient undermined the broader use of 
amnesty as an incentive for members of rebel groups to disarm. ${ }^{30}$ Interviews with former rebels from Ngudjolo's FNI and FRPI in Bunia who had been integrated into the Congolese army underscored this point. "This is the big problem with brassage," said one former FNI combatant: "The government gives us an amnesty, so we join the army and get a new uniform. But look what happened to Ngudjolo. He also got an amnesty but now he's in The Hague. We all wonder whether this will happen to us next." 31

Second, the ICC's interventions in the DRC potentially weaken the unofficial amnesty that underpins the extensive DDR program, which has demobilized and returned tens of thousands of rebels to Rwanda. This could have jeopardized the ICC's case against Bosco Ntaganda, a Rwandan-born former Rwandan Patriotic Army (RPA) officer who in July 2019 was convicted by the ICC on 18 charges of war crimes and crimes against humanity. ${ }^{32}$ As a Rwandan national, Ntaganda-who in 2013 surrendered to the ICC via the US embassy in Kigali-could have been eligible to participate in the DDR process and thus avoid prosecution by the Rwandan authorities.

The complications inherent in the Ntaganda case again highlight the potential for fraught relations between the ICC and, in this case, a UN-supported DDR process. A key challenge for the UN and other international bodies across Africa is that many support amnesty-based SSR and DDR as well as the ICC, highlighting a problem for peace mediators and related actors in navigating the new peacebuilding terrain since the advent of the Court. Similar sentiments to those of the former Nationalist and Integrationist Front (FNI) and Front for Patriotic Resistance in Ituri (FRPI) rebels above were expressed by former Congo-based rebels in the Mutobo demobilization center in Rwanda. As one young FDLR combatant said, "We heard what happened to Bosco. He was bigger than us and did the same as we did, coming across the border. Now he's at the ICC. Is that going to happen to us too?"33

The Uganda and DRC situations highlight the ICC's outright dismissal of national decisions to employ amnesties as a central means of conflict resolution. While the two governments in question have adopted deliberately ambiguous policies on amnesties - at times persisting with them even while cooperating with ICC investigations-amnesties have continued to be highly effective in encouraging combatants to lay down their arms and to reintegrate into their home communities. The ICC has insisted on international prosecutions while viewing amnesties as a 
means to entrench impunity, despite their long track record as effective tools of conflict mitigation, especially in terms of DDR in Uganda and the DRC. The Ugandan and Congolese experiences also highlight that the ICC's decision to overrule domestic amnesties in the cases of high-ranking suspects has dampened the effectiveness of amnesties for lower-ranking combatants, who often believe they too will be subject to criminal prosecution.

\section{Peace Negotiations}

This section analyzes the ICC's intersections with peace negotiations in Uganda and the DRC, which have invariably involved the fraught issue of whether to offer amnesties to high-ranking atrocity suspects. Three brief conceptual remarks are necessary to progress the "peace versus justice" debate that has dominated recent scholarly and policy discussions and to inform the empirical analysis below. First, a more helpful framing of the intersections of international justice and peace talks comes from Nick Grono and Adam O'Brien, who argue that the objectives of justice and peace, while not necessarily incompatible, are inevitably in tension. ${ }^{34}$ This counters the claim by numerous ICC officials and observers that peace and justice are always mutually reinforcing. ${ }^{35}$ Grono and O'Brien acknowledge the possibility of pursuing peace and justice sequentially but stress that some trade-off will probably be required, depending on the circumstances of particular conflict-affected societies and the nature of the proposed justice and peace interventions.

Second, it is important to recognize that what is being debated in situations such as Uganda and the DRC is rarely whether peace or justice are the desired outcomes-few actors would contest the necessity of both-but rather whether negotiations or prosecutions are the preferred processes by which to achieve these ends. A "negotiations versus prosecutions" formulation has the advantage of not preempting the result of particular mechanisms, while remaining open to the likelihood that such processes may have multiple (and even unexpected) outcomes. The "peace versus justice" debate assumes that peace negotiations produce peace and prosecutions produce justice, neither of which inherently holds. Peace talks can fail to achieve peace, just as trials can fail to achieve justice. Peace negotiations can also, if tailored in particular ways, pursue certain conceptions of justice that preclude prosecutions 
(including through conditional amnesties), while prosecutions can, if approached in contextually sensitive ways, contribute to peace.

Third, when analyzing the nature and impact of negotiations and prosecutions as processes, it is necessary to move beyond a fixation on the set-pieces of formal peace talks and criminal trials. A range of processes preceding, during, and following formal negotiations, as well as the prevailing environment in which they take place, are vital for understanding the impact that prosecutions have on negotiations and vice versa. Similarly, understanding the nature and effects of prosecutions involves more than an analysis of core legal practices such as investigations, courtroom arguments, and judgments. This also requires a close examination of the political, social, cultural, and economic context in which these legal processes unfold and their intersections with a wide range of other actors and mechanisms, including the national amnesty policies discussed above.

\section{Peace Negotiations in Uganda}

A central theme in the contestation over the Juba peace talks between the Ugandan government and the LRA is the role of the ICC in pushing the LRA to negotiate for peace. Various senior ICC officials and academic commentators have argued that without the threat of ICC prosecution, the LRA would never have considered negotiating with the Ugandan government. ${ }^{36}$ This argument is unconvincing in two key respects. The 2005 signing of the Comprehensive Peace Agreement (CPA) between the Sudanese government and the Sudan People's Liberation Movement (SPLM), which greatly weakened the LRA by threatening its bases in southern Sudan, occurred nine months before the ICC issued arrest warrants for the LRA leadership. While some LRA attacks continued in late 2005, the group's scope for violence was clearly curtailed by the CPA and the subsequent joint counterinsurgency against the rebels. As Ron Atkinson argues, the signing of the CPA pushed the LRA toward peace talks by forcing the Sudanese government to halt its support for the LRA, dispersing the LRA from its bases, and compelling the newly autonomous Government of South Sudan to deal with "foreign forces" including the LRA. This provided the grounds for the clandestine talks between the SPLM and the LRA that led to the Juba negotiations in $2006 .{ }^{37}$

Concerning the Juba talks themselves, debates center on whether blame for the collapse of the negotiations in 2008 should ultimately rest with the ICC. Such a perspective is widespread among many northern 
Ugandan civil society and community-level actors as well as in the commentary on the Juba talks. ${ }^{38}$ From the start of the talks in July 2006, foremost among the LRA's demands was the withdrawal of the ICC arrest warrants against its commanders, allowing them to take up the government's amnesty, participate in cleansing and reintegration rituals in northern Uganda and, according to some observers, secure exile in southern Sudan or elsewhere. ${ }^{39}$ The LRA's demand proved highly controversial, and the ICC stated shortly after that it would not withdraw the arrest warrants. ${ }^{40}$ Meanwhile, the government-that had initially backed the LRA's request-then claimed to support the ICC's refusal to grant it. ${ }^{41}$

Blaming the ICC solely for the breakdown in the Juba talks ignores the fact that the negotiations lasted two full years and led to the agreements on a range of highly contentious issues, all while the ICC warrants hung over the LRA leadership. This included the signing of the comprehensive political solutions agreement on May 2, 2007, providing a roadmap for addressing the root causes of the LRA rebellion; the accountability and reconciliation agreement signed on June 29, 2007, with an implementation protocol signed on February 19, 2008; the agreement on a permanent ceasefire signed on February 23, 2008; and the agreement on DDR signed on February 29, 2008. The final peace agreement which brought together all of the aforementioned agreements, however, was never signed, meaning these protocols could never be fully implemented. ${ }^{42}$ These important agreements counter the claim by Mark Kersten and others that the Government and the LRA never took the talks seriously. ${ }^{43}$

The ICC's intervention nevertheless weakened the Juba process from the outset. A structural effect of the ICC warrants was the fact that none of the five LRA commanders charged by the Court-including Vincent Otti, who had displayed an openness to negotiation during a previous process with former Ugandan government minister Betty Bigombe ${ }^{44}$ could lead the rebel delegation in Juba. Of the fifteen LRA delegates sent to Juba, only two, Colonel Lubwe Bwone and Lieutenant Colonel Santo Alit, were active commanders and had been present at failed LRAGovernment peace talks in 2004, thus bringing critical experience to the Juba process. A source of constant frustration for the mediation and advisory team to the talks was uncertainty over whether the LRA delegation spoke legitimately on behalf of the leadership in the bush and had the 
authority to enact the agreements signed in Juba, including the cessation to hostilities. ${ }^{45}$

The ICC warrants also fundamentally shaped the tenor and substance of the Juba negotiations. During and after the two-year process, the LRA said repeatedly that it would neither sign the remaining sections of the final agreement nor countenance laying down its arms and demobilizing its forces until the ICC warrants were withdrawn. ${ }^{46}$ Especially in the early stages of the talks, the issue of the arrest warrants was a major distraction to the five-point agenda. The first 18 months of the talks, particularly on the third agenda item of accountability and reconciliation, were dominated by discussions over modalities for removing the warrants or at least pausing the ICC investigations for one year, renewable under Article 16 of the Rome Statute. The UN and other international actors with access to the Juba negotiators stressed consistently that the Amnesty Act could not legally apply to the LRA commanders. This view caused anger among the LRA delegation and the Acholi civil society leadership that traveled to Juba. It also curtailed the mediators' flexibility in seeking common ground between the parties. ${ }^{47}$

Throughout the Juba process, the ICC intervened acerbically with a series of public statements, supported by various UN agencies and international human rights organizations, stating that the ICC arrest warrants must be enacted. ${ }^{48}$ These international interventions raised the temperature of the negotiations, framing various LRA proposals solely as attempts to extricate its leadership from the ICC warrants, and pressured all of the parties to narrow the parameters of substantive discussion. This amounted to significant over-reach by the ICC and its supporters and tainted the atmosphere and content of the Juba talks. ${ }^{49}$ The barbed statements by the ICC Prosecutor and other senior Court officials-particularly as the third agenda item on accountability and reconciliation was being discussed in 2007-complicated the mediators' task. ${ }^{50}$ Similar issues have arisen in other African peace negotiations conducted during ICC investigations and prosecutions, including the 2011 Doha talks between the Sudanese government and seven Darfuri rebel groups, in which amnesties were a central issue. ${ }^{51}$ While the Court was never the principal actor in catalyzing or undermining peace negotiations, it greatly stymied attempts to peacefully resolve the conflict between the LRA and the government. 


\section{Peace Negotiations in the Democratic Republic of the Congo}

Since the ICC launched investigations in the DRC in June 2004, the Court has overlapped with three major peace processes in which amnesty issues featured prominently: a series of informal peace negotiations with rebel groups mediated by the president of the Congolese TRC, Rev. JeanLuc Kuye, in 2005 and 2006; the 2008 Goma talks which concerned primarily the CNDP rebel group; and the 2013 Kampala talks, focused on the M23 rebellion. The ICC affected each of these processes differently, echoing some features of the Uganda case while diverging in several important ways.

First, the Congolese TRC incorporated an important element of peace mediation and negotiation. Article 5 of the TRC Statute broadened the commission's mandate to include active conflict resolution, described as "the prevention or management of conflicts as they occur through mediation between divided communities." 52 Kuye and several TRC commissioners attempted to resolve conflict by traveling to Kisangani, Bukavu, Goma, Rutshuru, and elsewhere to talk to protagonists. ${ }^{53}$

Kuye argued that the ICC hampered the TRC's efforts because belligerents refused to confess to crimes or to cooperate with mediators for fear of evidence being used against them in criminal trials, either through the ICC or the domestic courts. "The ICC came up forcefully in our discussions with several rebel leaders, including [CNDP leader Laurent] Nkunda," Kuye said. "We would start talking to them, make good progress, then the conversation would stop. They didn't want to incriminate themselves, even when we stressed that the amnesty was in place." $" 54$ This situation echoes challenges in other countries such as Sierra Leone and Timor-Leste that have simultaneously deployed trials and truth commissions. As various commentators have argued, the threat of prosecutions in such cases often deters even lower-ranking actors from appearing before truth commissions. ${ }^{55}$

In January 2008, the Goma peace talks between the Congolese government and 22 rebel groups-but centering on the CNDP-began to show the more direct influence of the ICC, including flow-on effects from the concurrent Ugandan peace talks. The ICC had little impact on the government or rebel parties in Goma but influenced substantially the work of the international mediators. The CNDP pressed hard for a blanket amnesty that would include charges of genocide, war crimes, and crimes against humanity, arguing that the 2005 amnesty law 
was too restrictive in this regard. ${ }^{56}$ Several observers who interviewed the European Union (EU) and other international mediators in Goma, however, underline the "invisible presence" 57 of the ICC over the negotiations, principally on the legality of amnesties for international crimes. In particular, the mediators wanted to avoid the heated contestation over amnesties and international prosecutions that dominated the Ugandan peace talks. ${ }^{58}$

The UN, however, found itself in a more complicated position, having supported through MONUC the use of blanket amnesties for the Ituri rebel leaders in 2006, discussed in the previous section, while supporting the EU opposition to amnesties for international crimes during the Goma process. Tatiana Carayannis observes that the UN found it an "embarrassment" that the final Goma agreement involved a peace deal with CNDP deputy leader, Bosco Ntaganda. ${ }^{59}$ At the time of the Goma talks, a sealed ICC arrest warrant for Ntaganda was in place (issued on August 22, 2006, it was unsealed soon after the Goma talks on April $28,2008) .{ }^{60}$ Laura Davis argues that rumors of the ICC warrant against Ntaganda abounded in Goma and reinforced the EU's and UN's stringent opposition to amnesties for international crimes. They did not want to jeopardize possible ICC moves against Ntaganda in the way that they perceived the Ugandan Amnesty Act to have done in the ICC cases against the LRA leaders. ${ }^{61}$

Throughout 2013, the Kampala peace talks between the Congolese government and the M23 rebels-precipitated by the M23 capture of Goma in November 2012 - again showed the important influence of the ICC. Echoing the 2008 Goma talks between the Congolese government and the M23's predecessor organization, the CNDP, the rebel leaders pressed hard for a blanket amnesty that would cover international crimes as well as a favorable reintegration into the Congolese army. The parties refused to sign a joint agreement and instead issued two separate declarations in Nairobi in December 2013. As a result of the talks, an amnesty law was passed in January 2014 that covered "insurrectional acts" but not genocide, war crimes, or crimes against humanity. Only 29 M23 fighters were granted amnesty under the law, while the Congolese government deemed 78 M23 members ineligible for reintegration into the Armed Forces of the Democratic Republic of the Congo (FARDC) and issued arrest warrants for 19 M23 officials at large in Rwanda and Uganda. ${ }^{62}$ 
Taken together, these three peace processes-the TRC dialogues in 2005-2006, the Goma talks in 2008 and the Kampala talks in 2013highlight the various ways in which the ICC has often discouraged conflict actors to see dialogue as a means for peace and pushed mediators to eschew amnesties, even if these represent important incentives to bring belligerents to the negotiating table. These peace negotiations also underscore the variability of the UN, the Congolese government, and other important actors on whether prosecutions, as opposed to dialogue or the offer of amnesties, represent the most effective responses to mass crimes.

\section{CONCLUSION}

Viewed side by side, the Ugandan and DRC cases highlight the crucial but diverse ways in which the ICC impinges on national amnesties and peace processes. Throughout peace negotiations in the two countries, the ICC was one-but never the decisive-barrier to peace, often exacerbating more fundamental challenges. That the Ugandan and Congolese governments, the UN and other international bodies that ostensibly support the ICC so regularly advocate the use of amnesties-when confronted with the need to facilitate peace talks, DDR, SSR, and truth commissions-shows the continued utility of amnesty as a means to resolve mass conflict. While the ICC has rendered the Rome Statute an unavoidable touchstone in debates over amnesty and the conduct of peace talks today, these actors are reluctant to jettison amnesty entirely and to fully embrace international prosecutions. Meanwhile, the Court's attempts to influence peace negotiations and strident opposition to amnesties - seen most vividly during the Juba talks — risk alienating actors who are directly embroiled in attempts to mitigate conflict and do not have the luxury of ignoring context and consequences.

\section{Key Recommendations}

International policymakers and practitioners should respond in several ways to these problems produced by the ICC.

1. Reassess and reorient probibitions against amnesties. The routinely stated prohibition against amnesties for high-level atrocity perpetrators-and the prosecutions-at-all-costs approach this entailsreflects neither international law, as it currently holds, nor the 
practice of the UN and many domestic governments in Africa. There should be more explicit recognition that many of the processes favored by the UN and other international actors to resolve mass conflict, including DDR and SSR, depend on offering amnesties to combatants in exchange for their cooperation. As highlighted above, the stance by the ICC and many of its supporters that amnesties are permissible for low-level perpetrators but must be prohibited for high-ranking perpetrators belies the empirical reality that the latter also disincentivizes many low-level actors from accepting amnesties and participating in processes such as DDR and SSR. International actors must therefore refrain from anti-amnesty rhetoric and advocate instead flexibility and context-specific responses to mass crimes. This may, under certain circumstances, include prosecutions but should equally allow principled discussion over the use of conditional amnesties and other lenient forms of accountability that promote peacebuilding. One key effect of the ICC's intervention in African conflict zones over the last 15 years has been the narrowing of potential remedies available to African actors in seeking the sustainable resolution of mass conflicts. This has denied peace negotiators and other conflict mitigators the flexibility necessary to incentivize belligerents to lay down their arms and to formulate responses that address the complex causes of violence in the long term.

2. Reinforce the role of local actors. As part of this reorientation, international actors must also reinforce the role of local actorsdomestic policymakers, civil society, and affected communities-in determining the most context-appropriate and effective means to accountability and peace. Many domestic mediators during peace talks in Uganda and the DRC expressed a sense of powerlessness in the face of external insistence on ICC prosecutions. The experiences of Uganda, the DRC, and other African states highlight the overly controlling nature of international intervention-including the over-reach of the ICC into delicate domestic peace processesand the need for much greater dedication to domestic ownership. The precise contribution of the ICC to peacebuilding efforts across Africa has been often stated but rarely proven. What is much clearer is the ICC's track record of interfering directly in key processes of conflict mitigation-namely amnesties, peace talks, DDR, SSR, and truth commissions-with the net result that, over the last 
17 years, the Court has made peace across Africa much tougher to achieve. The task for the ICC and international actors now is to tailor the Court's work more directly to the pursuit of peace, while minimizing its capacity to undermine other vital peacebuilding efforts.

\section{Notes}

1. See, for example, Nicola Palmer, Courts in Conflict: Interpreting the Layers of Justice in Post-genocide Rwanda (Oxford: Oxford University Press, 2015) and Tim Kelsall, Culture Under Cross-Examination: International Justice and the Special Court for Sierra Leone (Cambridge and New York: Cambridge University Press, 2009).

2. See, for example, Darryl Robinson, "Serving the Interests of Justice: Amnesties, Truth Commissions and the International Criminal Court," European Journal of International Law 14, no. 3 (2003): 481-505; Max Pensky, "Amnesty on Trial: Impunity, Accountability and the Norms of International Law," Ethics and Global Politics 1, no. 1-2 (2008): 140; Louise Mallinder, Amnesty, Human Rights and Political Transitions: Bridging the Peace and Justice Divide (Hart Publishing, 2008); and Mark Freeman, Necessary Evils: Amnesties and the Search for Justice (Cambridge: Cambridge University Press, 2011).

3. See, for example, Diane F. Orentlicher, "Settling Accounts: The Duty to Prosecute Human Rights Violations of a Prior Regime," Yale Law Journal 100, no. 8 (1991): 2537-2615; Carlos S. Nino, "The Duty to Punish Past Abuses of Human Rights Put into Context: The Case of Argentina," Yale Law Journal 100, no. 8 (1991): 2619-2640; Diane F. Orentlicher, "A Reply to Professor Nino," Yale Law Journal 100, no. 8 (1991): 2641-2643; and Robert H. Mnookin, "Rethinking the Tension between Peace and Justice: The International Criminal Prosecutor as Diplomat," Harvard Negotiation Law Review 18 (2013): 145-172.

4. Building a Future on Peace and Justice, Nuremberg conference, June 2007.

5. Ibid.

6. Luis Moreno-Ocampo, "Building a Future on Peace and Justice," speech at Nuremberg conference, June 24, 2007, http://www.icc-cpi. int/NR/rdonlyres/4E466EDB-2B38-4BAF-AF5F-005461711149/143 825/LMO_nuremberg_20070625_English.pdf.

7. A 2009 report on amnesties by the UN Office of the High Commissioner for Human Rights states, "The United Nations policy of opposing amnesties for war crimes, crimes against humanity, genocide or gross violations of human rights, including in the context of peace negotiations, 
represents an important evolution, grounded in long experience" ("Ruleof-Law Tools for Post-Conflict States: Amnesties," United Nations Office of the High Commissioner for Human Rights, 2009).

8. See, for example, S. Nouwen, Complementarity in the Line of Fire: The Catalysing Effect of the International Criminal Court in Uganda and Sudan (Cambridge: Cambridge University Press, 2013), 18.

9. A. Greenawalt, "Complementarity in Crisis: Uganda, Alternative Justice and the International Criminal Court," Virginia Journal of International Law 50, no. 1 (2009): 133.

10. Quoted in M. Scharf, "The Amnesty Exception to the Jurisdiction of the International Criminal Court," Cornell International Law Journal 32 (1999): 522.

11. For a broader discussion of the extent to which the Rome Statute is a "flexible instrument" affording the Prosecutor in particular a high degree of discretion, see K. Ambos, "The Legal Framework of Transitional Justice: A Systematic Study with a Specific Focus on the ICC," in Building a Future on Peace and Justice: Studies on Transitional Justice, Peace and Development, K. Ambos, J. Large, and M. Wierda (eds.) (Springer, 2014), 20.

12. See, for example, Pensky, "Amnesty on Trial," op. cit.; Mallinder, Amnesty, Human Rights and Political Transitions, op. cit.; Freeman, Necessary Evils, op. cit.; and M. Freeman and M. Pensky, "The Amnesty Controversy in International Law," in Amnesty in the Age of Human Rights Accountability: Comparative and International Perspectives, F. Lessa and L. Payne (eds.) (Cambridge: Cambridge University Press, 2012), 42-65.

13. See, for example, J. Snyder and L. Vinjamuri, "Trials and Errors: Principle and Pragmatism in Strategies of International Justice," International Security 28, no. 3 (Winter 2003/2004): 5-44; and L. Vinjamuri, "Deterrence, Democracy and the Pursuit of International Justice," Ethics of International Affairs 24, no. 2 (2010): 191-211.

14. "Statement by the Chief Prosecutor Luis Moreno-Ocampo," International Criminal Court, Office of the Prosecutor, July 12, 2006, https:// www.icc-cpi.int/NR/rdonlyres/3255817D-FD00-4072-9F58-FDB869 F9B7CF/143834/LMO_20051014_Englishl.pdf; See also Ocampo's quotes in F. Osike and H. Musaka, "ICC Insists Kony Must Face Prosecution," New Vision, October 11, 2007, https://www.globalpol icy.org/component/content/article/164/28647.html; "Benchmarks for Assessing Possible National Alternatives," Human Rights Watch, op. cit.; "Amnesty International Letter to Security Council," Amnesty International, op. cit.

15. G. Khadiagala, "The Role of the Acholi Religious Leaders Peace Initiative (ARLPI) in Peace Building in Northern Uganda," Appendix in "The 
Effectiveness of Civil Society Initiatives in Controlling Violent Conflicts and Building Peace: A Study of Three Approaches in the Greater Horn of Africa," USAID/Management Systems International, March 2001, 4-6.

16. Author's telephone interview, Amnesty Commission Official, Kampala, January 17, 2017.

17. C. Blattman and J. Annan, "On the Nature and Causes of LRA Abduction: What the Abductees Say," in The Lord's Resistance Army: Myth and Reality, T. Allen and K. Vlassenroot (eds.) (London: Zed Books, 2010), 133; A. Branch, Displacing Human Rights: War and Intervention in Northern Uganda (Oxford: Oxford University Press, 2011), 134-135; "Whose Justice? Perceptions of Uganda's Amnesty Act 2000-Working Paper No. 15," Refugee Law Project, February 28, 2005; "Forgotten Voices: A Population-Based Survey of Attitudes about Peace and Justice in Northern Uganda," International Center for Transitional Justice and the Human Rights Center, University of California, Berkeley, July 2005; and "When the War Ends: A Population-Based Survey on Attitudes About Peace, Justice and Social Reconstruction in Northern Uganda," International Center for Transitional Justice and the Human Rights Center, University of California, Berkeley, December 2007.

18. See, for example, "A Renewed Promise for Peace and Justice: The Reinstatement of Uganda's Amnesty Act 2000," Refugee Law Project, May 29, 2013.

19. B. Afako, "Reconciliation and Justice: 'Mato Oput' and the Amnesty Act," in Protracted Conflict, Elusive Peace: Initiatives to End the Violence in Northern Uganda, O. Lucima (ed.), Conciliation Resources/Accord, 2002, 65.

20. "Negotiating Peace: Resolution of Conflicts in Uganda's West Nile Region-Working Paper No. 12," Refugee Law Project, June 2004, 8-21; see also, A. Bogner and D. Neubert, "Negotiated Peace, Denied Justice? The Case of West Nile (Northern Uganda)," Africa Spectrum 48, no. 3 (2013): 55-84.

21. "Making Peace Our Own: Victims' Perceptions of Accountability, Reconciliation and Transitional Justice in Northern Uganda," United Nations Office of the High Commissioner for Human Rights, 2007, section II.

22. United Nation, "Making Peace Our Own."

23. See, for example, A. Macdonald, "Exploring the Transitional Justice Implementation Gap," International Journal of Transitional Justice 13, no. 2 (July 2019): 225-248; and P. Clark, Distant Justice: The Impact of the International Criminal Court on African Politics (Cambridge: Cambridge University Press, 2018), chapter 7.

24. Author's interview, Justice Peter Onega, Chairman, Ugandan Amnesty Commission, Kampala, Uganda March 3, 2006; “Ongwen's Justice Dilemma: Perspectives from Northern Uganda," Refugee Law Project, 
26 January 2015; For further views of various civil society actors on this issue, see "War Crimes Trial May Affect LRA Defections-Analysts," ReliefWeb, July 29, 2011, http://reliefweb.int/report/uganda/war-cri mes-trial-may-affect-lra-defections-analysts.

25. "Demobilisation," Rwanda Demobilisation and Reintegration Commission, http://www.demobrwanda.gov.rw/index.php?id=81.

26. See, for example, J. Gettleman, "An Interview with Joseph Kabila," The New York Times, April 3, 2009, http://www.nytimes.com/2009/04/ 04/world/africa/04kabilatranscript.html.

27. "DR Congo Militias Lay Down Arms," BBC, July 27, 2006, http:// news.bbc.co.uk/1/hi/world/africa/5219076.stm; For further discussion of the overlaps between the ICC and these Ituri cases, see K. Rodman, "The Peace versus Justice Debate at the ICC: The Case of the Ituri Warlords in the Democratic Republic of the Congo," Colby College workshop paper, March 2016, http://web.colby.edu/karodman/files/ 2016/03/ICCWorkshop_DRC.pdf.

28. Acronym derived from the French title, Mission de l'Organisation des Nations Unies en République Démocratique du Congo.

29. Quoted in T. McConnell, "Measures to Keep Peace in Congo Draw Fire," Christian Science Monitor, September 5, 2006, https://www.csmonitor. com/2006/0905/p04s02-woaf.html.

30. This also challenges the view expressed by some transitional justice scholars that trials can follow amnesties, delivering the perceived benefits of both approaches. See, for example, T. Olsen, L. Payne, and A. Reiter, Transitional Justice in Balance: Comparing Processes, Weighing Efficacy (United States Institute of Peace, 2010).

31. Author's interview, Integrated Former FNI Combatant, Bunia, August $24,2011$.

32. "ICC Trial Chamber VI Declares Bosco Ntaganda Guilty of War Crimes and Crimes against Humanity," International Criminal Court, July 8, 2019, https://www.icc-cpi.int/Pages/item.aspx?name=prl466.

33. Author's interview, Former FDLR Combatant, Mutobo, April 19, 2013.

34. N. Grono and A. O'Brien, "Justice in Conflict? The ICC and Peace Processes," in Courting Conflict: Justice, Peace and the ICC in Africa, N. Waddell and P. Clark (eds.) (Royal African Society, 2008), 13-20.

35. See, for example, Ocampo's comments at F. Osike and H. Musaka, "ICC Insists Kony Must Face Prosecution," New Vision, October 11, 2007, https://www.globalpolicy.org/international-justice/the-intern ational-criminal-court/icc-investigations/uganda.html.

36. See, for example, P. Akhavan, "The Lord's Resistance Army Case: Uganda's Submission of the First State Referral to the International Criminal Court," American Journal of International Law 99, no. 2 (April 2005): 
403-421, 404; C. Chung, "The Punishment and Prevention of Genocide: The International Criminal Court as a Benchmark of Progress and Need," Case Western Reserve Journal of International Law 40, no. 1 (2007-2008): 233-240.

37. R. Atkinson, “The Realists in Juba?' An Analysis of the Juba Peace Talks," in The Lord's Resistance Army: Myth and Reality, T. Allen and K. Vlassenroot (eds.) (London: Zed Books, 2011): 207-214.

38. Author's interviews, Civil Society Representatives, Gulu and Lira, 20082015.

39. Author's interview, Alphonse Owiny-Dollo, Lira, 10 November 2006. The LRA also proposed that Uganda be governed under a federalist system that would afford northern districts greater autonomy (IRIN News, "Uganda: Rebels Propose Federalist Solution at Juba Talks," October 11, 2006, http://www.irinnews.org/report.aspx?rep ortid=61303).

40. International Criminal Court, Pre-Trial Chamber II, "Submission of Information on the Status of the Execution of the Warrants of Arrest in the Situation in Uganda," Situation in Uganda, The Prosecutor $v$. Joseph Kony, Vincent Otti, Raska Lukwiya, Okot Odhiambo and Dominic Ongwen, October 6, 2006.

41. "Museveni Says ICC Indictments Will Stay Until Peace Agreement Signed," Daily Monitor, October 27, 2006, http://www.ugandacan.org/ item/1781.

42. M. Tran, "Ugandan Rebel Leader Fails to Sign Peace Deal," The Guardian, April 11, 2008, https://www.theguardian.com/world/2008/ apr/11/uganda.

43. M. Kersten, Justice in Conflict: The Effects of the International Criminal Court's Interventions on Ending Wars and Building Peace (Oxford: Oxford University Press, 2016): 101-104.

44. Author's interviews, Betty Bigombe, Former Ugandan Government Minister and Peace Mediator, Gulu, March 10, 2006; Lars Erik Skaansar, UN Humanitarian Affairs Officer and UN Special Envoy to the Northern Uganda Peace Process, Gulu, March 8, 2006; Sam Kolo, Former LRA Commander, Gulu, March 10, 2006.

45. Author's interviews, Members of Juba Mediation Team, Juba and Kampala, February 10-21, 2007.

46. "LRA Leader Kony Reportedly Willing to Face Trial in Uganda, Not The Hague," Daily Monitor, December 20, 2006.

47. Author's interviews, Civil Society Representatives, Juba and Gulu, June 2007-February 2008; Barney Afako, Legal Advisor to Juba Mediation Team, London, March 2, 2007.

48. See, for example, ICC-OTP, "Statement by the Chief Prosecutor Luis Moreno-Ocampo," July 12, 2006; Ocampo's quotes in Osike and 
Musaka, "ICC Insists Kony Must Face Prosecution," op. cit.; Human Rights Watch, "Benchmarks for Assessing Possible National Alternatives," op. cit.; Amnesty International, "Amnesty International Letter to Security Council," op. cit.

49. For an analysis of the power imbalances around peace versus justice debates at Juba, highlighting that the more powerful actors were broadly on the "justice" side and were largely successful at sidelining those on the "peace" side, see K. Armstrong, "Justice without Peace? International Justice and Conflict Resolution in Northern Uganda," Development and Change 45, no. 3 (2014): 589-607.

50. Author's interviews, Members of Juba Mediation Team, Juba and Kampala, February 10-21, 2007.

51. Nouwen, Complementarity in the Line of Fire, 317.

52. "Loi n ${ }^{\circ}$ 04/018 du 30 juillet 2004 Portant Organisation, Attributions et Fonctionnement de la Commission Vérité et Réconciliation," Government of the Democratic Republic of the Congo, July 30, 2004, Article 5.

53. Author's interview, Jean-Luc Kuye, President, Truth and Reconciliation Commission, Kinshasa, January 24, 2006.

54. Ibid.

55. See, for example, K. Lanegran, "Truth Commissions, Human Rights Trials and the Politics of Memory," Comparative Studies of South Asia, Africa and the Middle East 25, no. 1 (2005): 111-121.

56. L. Davis, "Case Study: Democratic Republic of Congo," International Justice and the Prevention of Atrocities project, European Council on Foreign Relations, November 2013, 4; "Peace Agreement between the Government and the CNDP," Government of the Democratic Republic of the Congo, Goma, March 23, 2009, Article 3.

57. L. Davis, "Power Shared and Justice Shelved: the Democratic Republic of Congo," International Journal of Human Rights 17, no. 2 (2013): 289-306, 9.

58. L. Davis and P. Hayner, "Difficult Peace, Limited Justice: Ten Years of Peacemaking in the DRC," International Center for Transitional Justice, March 2009, 11.

59. T. Carayannis, "The Challenge of Building Sustainable Peace in the DRC," Centre for Humanitarian Dialogue, Background Paper, July 2009, p. 13.

60. International Criminal Court, "Ntaganda Case," Situation of the Democratic Republic of the Congo, The Prosecutor v. Bosco Ntaganda.

61. L. Davis, "The EU and Post-conflict Interventions: Supporting Reform or Business as Usual? The Democratic Republic of Congo," Conference Paper, 2011, 9, http://www.gu.se/digitalAssets/1349/1349860_c onf-2011-davis.pdf. 
62. Social Science Research Council, “Consolidating the Peace: Closing the M23 Chapter," Paper prepared on behalf of the DRC Affinity Group, December 2014, 8 .

Open Access This chapter is licensed under the terms of the Creative Commons Attribution 4.0 International License (http://creativecommons.org/licenses/ by/4.0/), which permits use, sharing, adaptation, distribution and reproduction in any medium or format, as long as you give appropriate credit to the original author(s) and the source, provide a link to the Creative Commons license and indicate if changes were made.

The images or other third party material in this chapter are included in the chapter's Creative Commons license, unless indicated otherwise in a credit line to the material. If material is not included in the chapter's Creative Commons license and your intended use is not permitted by statutory regulation or exceeds the permitted use, you will need to obtain permission directly from the copyright holder.

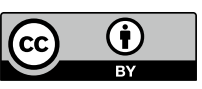

